\title{
Pleural Diseases in the Molecular Era - Time for More Answers: Introduction
}

\author{
Marios E. Froudarakis \\ Department of Pneumonology, Medical School, Democritus University of Thrace, University Hospital of \\ Alexandroupolis, Alexandroupolis, Greece
}

It has been 30 years since Richard Light defined the criteria that totally changed the 'world of pleura', and his research still seems so fresh; no better criteria exist today to differentiate transudates from exudates. Other classic markers tested in pleural fluid by different authors have shown little accuracy in the differential diagnosis of pleural effusions even between malignant and nonmalignant effusions [1].

In the dawn of the molecular era, research is focused on new markers, such as genes, matrix metalloproteinases, and specific receptors, tested in pleural fluid either for diagnosis or to understand the mechanisms involved in pleural diseases. However, pleural fluid may not be sufficient at present to fully study the pleura, and therefore 'tissue is the issue' [2]. A major tool to obtain more tissue is thoracoscopy to diagnose and/or to understand the mechanisms and pathophysiology of different diseases of the pleura. A better understanding of the molecular and cellular mechanisms helps to identify new targets and therefore new compounds for effective treatment $[3,4]$.

The present thematic review series focuses on 6 different issues of pleural diseases. Patients with lung diseases of unknown etiology and limited effective therapy are rare (orphan) [5] but may have pleural effusion either as a presenting syndrome or during disease evolution. Little is known regarding the pathogenetic mechanisms of orphan diseases, and even less is known about the occur-

\section{KARGER}

Fax +4161306 1234

E-Mail karger@karger.ch

www.karger.com
(C) 2012 S. Karger AG, Basel

0025-7931/12/0831-0002\$38.00/0

Accessible online at:

www.karger.com/res rence of pleural effusion in this patient population. Also, a major unanswered question is whether the occurrence of pleural effusion has any prognostic value. Thus, an issue of the present thematic review series is focused on the advances in the understanding of the mechanisms of pleural effusion in patients with orphan diseases. Prof. Demosthenes Bouros et al. will cover this issue under the title: 'Mechanisms of Pleural Involvement in Orphan Diseases'.

Lung cancer remains the most common fatal malignancy despite more aggressive therapies. Patients with NSCLC who undergo radical surgery are few (10\%) and they are likely to be cured. In advanced stage disease, first-line chemotherapy has shown little improvement in survival, and second-line chemotherapy, in few patients in good shape, has globally shown little effect. The development of novel targeted therapies has given new hope to both physicians and patients [6]. Pleural metastatic effusion in patients with NSCLC has been reclassified by the IASLC [7] as M1a disease since the outcome of these patients is generally poor [8], and behaves like distant metastasis. Also, patients with SCLC and pleural metastasis have an intermediate prognosis between limited and diffused disease and the 'mystery' of this behavior should be clarified by further clinical studies [9]. In lung cancer, although the disease remains in the same hemithorax, the explanation for this 'aggressive behavior' of pleural in- 
volvement might be found in the study of tumor biology (pathways of carcinogenesis). Therefore, a chapter explaining late molecular findings for mechanisms of carcinogenesis and thus possible new targeted therapies is necessary. Prof. Marios Froudarakis will discuss this issue under the title: 'Pleural Effusion in Lung Cancer: More Questions than Answers'.

Malignant pleural mesothelioma (MPM) is a neoplasm with increasing incidence and a poor prognosis. Accurate histological diagnosis and staging of the disease are problematic since differentiation between MPM and benign mesothelial hyperplasia or adenocarcinoma is a matter of discussion, and all of the known methods have raised significant questions with regard to assessment of tumor extension [10,11]. A recent study [12] investigating the role of radical surgery (extrapleural pneumonectomy) as part of a multimodality treatment has failed to show any improvement in survival compared to chemotherapy in patients with early stage disease. Chemotherapy in the advanced stage, associating pemetrexed with platinum, is the standard of care as this combination has shown a small but significant improvement in survival [10], although no direct comparison with best supportive care, especially talc pleurodesis, exists [13]. Many novel biological compounds are being tested in clinical or preclinical studies, and we must wait some years for the results. It is true that the study of this particular tumor has been delayed for some 30 years, yet the interest has importantly increased in recent years and many papers focus on the biological factors in order to understand the invasiveness of MPM. Therefore, an important issue to report is the advances in research on MPM and translation of findings into clinical applications. Prof. Philippe Astoul and Prof. Arnaud Scherpereel will address this issue under the title: 'Mesothelioma: from Bench to Bedside'.

In pleural malignant disease, surgery and classical therapeutic approaches, including intravenous chemotherapy, have proved to have little effect overall; local treatment might be a promising alternative. The effect of intrapleural instillation of chemotherapeutic agents [14] or cytokines [15] in patients has been studied in older, well-designed, large controlled trials, while newer compounds are in preclinical phases $[16,17]$. The development of novel therapies such as gene therapy $[18,19]$ or targeted therapy (antiangeiogenetics, tyrosine kinase inhibitors) is very attractive, especially because we have newer tools to directly investigate the local effect $[3,4]$, such as narrow band imaging (NBI) [20]. Prof. Daniel Sterman will cover this issue under the title: 'Rationale for Novel Intrapleural Therapies'.
'If you cannot treat, then do not harm'. Pleurodesis seems to agree very well with this Hippocratic sentence, offering a comfortable end of life to patients with malignant pleural disease. The best cost-effective compound is the calibrated, asbestos-free, large particle, French talc. Although its inflammatory effect has been proved in the last 5 years [21,22], its mechanism of action is still under investigation. Furthermore, recent studies seem to show a local antitumor effect by induction of apoptosis in cancer cells [23] by alteration of the angiostasis balance via endostatin [24]. Prof. Francisco Rodriguez-Panadero will discuss this issue under the title: 'Mechanisms of Pleurodesis'.

Primary spontaneous pneumothorax (PSP) is a significant health problem. There have been improvements in diagnostic procedures and therapeutic approaches [25]. The pathogenesis of PSP is another field of discussion [25]. A recent hypothesis based on investigations using autofluorescence thoracoscopy $[26,27]$ is that it is more likely to be a disease of the pleura (pleural porosity) than a local defect $[25,28]$. Whether this is due to diffused pleural inflammation [29] or other factors remains to be evaluated, and our last chapter will try to help in this regard by reviewing newer data. Prof. Jean-Marie Tschopp et al. will address this issue under the title: 'Primary Spontaneous Pneumothorax: A Diffuse Disease of the Pleura'.

Overall, many more questions than answers are pending in pleural disease since there is a delay in clinical and basic research compared to other more classical respiratory diseases. This is in a great part due to the fatalism and nihilism of physicians facing patients with diseases of unknown pathogenesis and with poor survival. Also, the interest of industry in such 'unattractive' diseases is limited since the benefits are poor compared to those of other classical respiratory diseases. However, in recent years, some 'romantic' physicians and researchers have made important efforts to understand the pleural disease pathogenesis, which this thematic series will try to report.

References
1 Froudarakis ME: Diagnostic work-up of pleural effusions. Respiration 2008;75:4-13.

2 Sriram KB, Relan V, Clarke BE, Duhig EE, Yang IA, Bowman RV, Lee YC, Fong KM: Diagnostic molecular biomarkers for malignant pleural effusions. Future Oncol 2011;7: 737-752.

3 Froudarakis ME: New challenges in medical thoracoscopy. Respiration 2011;82:197-200.

-4 Froudarakis ME, Noppen M: Medical thoracoscopy: new tricks for an old trade. Respiration 2009;78:373-374. 
$\checkmark 5$ Cordier JF: Orphan diseases, rare diseases, time to get mobilised (in French). Rev Prat 2006;56:123-124.

6 6 Froudarakis ME, Briasoulis E: Advanced non-small cell lung cancer: on relapse rechallenge the tumor, not the patient. BMC Res Notes 2010;3:195.

7 Goldstraw P, Crowley J, Chansky K, Giroux DJ, Groome PA, Rami-Porta R, Postmus PE, Rusch V, Sobin L: The IASLC Lung Cancer Staging Project: proposals for the revision of the TNM stage groupings in the forthcoming (seventh) edition of the TNM Classification of Malignant Tumours. J Thorac Oncol 2007; 2:706-714.

-8 Sugiura S, Ando Y, Minami H, Ando M, Sakai S, Shimokata K: Prognostic value of pleural effusion in patients with non-small cell lung cancer. Clin Cancer Res 1997;3:4750.

-9 Shepherd FA, Crowley J, Van Houtte P, Postmus PE, Carney D, Chansky K, Shaikh Z, Goldstraw P: The International Association for the Study of Lung Cancer lung cancer staging project: proposals regarding the clinical staging of small cell lung cancer in the forthcoming (seventh) edition of the tumor, node, metastasis classification for lung cancer. J Thorac Oncol 2007;2:1067-1077.

10 Scherpereel A, Astoul P, Baas P, Berghmans $\mathrm{T}$, Clayson $\mathrm{H}$, de Vuyst P, Dienemann $\mathrm{H}$, Galateau-Salle F, Hennequin C, Hillerdal G, Le Pechoux C, Mutti L, Pairon JC, Stahel R, van Houtte P, van Meerbeeck J, Waller D, Weder W: Guidelines of the European Respiratory Society and the European Society of Thoracic Surgeons for the management of malignant pleural mesothelioma. Eur Respir J 2010;35:479-495.

-11 van Meerbeeck JP, Scherpereel A, Surmont VF, Baas P: Malignant pleural mesothelioma: the standard of care and challenges for future management. Crit Rev Oncol Hematol 2011;78:92-111.

-12 Treasure T, Lang-Lazdunski L, Waller D, Bliss JM, Tan C, Entwisle J, Snee M, O’Brien M, Thomas G, Senan S, O’Byrne K, Kilburn LS, Spicer J, Landau D, Edwards J, Coombes G, Darlison L, Peto J: Extra-pleural pneumonectomy versus no extra-pleural pneumonectomy for patients with malignant pleural mesothelioma: clinical outcomes of the Mesothelioma and Radical Surgery (MARS) randomised feasibility study. Lancet Oncol 2011;12:763-772.
13 Aelony Y: Raltitrexed and pemetrexed studies in mesothelioma have not shown improved quality of life nor prolonged survival compared with effective pleurodesis with thoracoscopic talc poudrage. J Clin Oncol 2006;24:4667, author reply 4667-4668.

14 Markman M, Cleary S, Pfeifle C, Howell SB: Cisplatin administered by the intracavitary route as treatment for malignant mesothelioma. Cancer 1986;58:18-21.

15 Astoul P, Picat-Joossen D, Viallat JR, Boutin C: Intrapleural administration of interleukin-2 for the treatment of patients with malignant pleural mesothelioma: a phase II study. Cancer 1998;83:2099-2104.

6 Greillier L, Monjanel-Mouterde S, Fraticelli A, Devictor-Pierre B, Bouvenot J, Coltel N, Lamarche G, Astoul P: Intrapleural administration of pemetrexed: a pharmacokinetic study in an animal model. J Thorac Oncol 2009;4:404-408.

17 Froudarakis ME, Greillier L, MonjanelMouterde S, Koutsopoulos A, DevictorPierre B, Guilhaumou R, Karpathiou G, Botaitis S, Astoul P: Intrapleural administration of lipoplatin in an animal model. Lung Cancer 2011;72:78-83.

18 Sterman DH, Recio A, Carroll RG, Gillespie CT, Haas A, Vachani A, Kapoor V, Sun J, Hodinka R, Brown JL, Corbley MJ, Parr M, Ho M, Pastan I, Machuzak M, Benedict W, Zhang XQ, Lord EM, Litzky LA, Heitjan DF, June $\mathrm{CH}$, Kaiser LR, Vonderheide RH, Albelda SM, Kanther M: A phase I clinical trial of single-dose intrapleural IFN-beta gene transfer for malignant pleural mesothelioma and metastatic pleural effusions: high rate of antitumor immune responses. Clin Cancer Res 2007;13:4456-4466.

19 Sterman DH, Haas A, Moon E, Recio A, Schwed D, Vachani A, Katz SI, Gillespie CT, Cheng G, Sun J, Papasavvas E, Montaner LJ, Heitjan DF, Litzky L, Friedberg J, Culligan M, June CH, Carroll RG, Albelda SM: A trial of intrapleural adenoviral-mediated interferon-\{alpha\}2b gene transfer for malignant pleural mesothelioma. Am J Respir Crit Care Med 2011, E-pub ahead of print.
20 Ishida A, Ishikawa F, Nakamura M, Miyazu YM, Mineshita M, Kurimoto N, Koike J, Nishisaka T, Miyazawa T, Astoul P: Narrow band imaging applied to pleuroscopy for the assessment of vascular patterns of the pleura. Respiration 2009;78:432-439.

21 Psathakis K, Calderon-Osuna E, RomeroRomero B, Martin-Juan J, Romero-Falcon A, Rodriguez-Panadero F: The neutrophilic and fibrinolytic response to talc can predict the outcome of pleurodesis. Eur Respir J 2006;27:817-821.

22 Froudarakis ME, Klimathianaki M, Pougounias M: Systemic inflammatory reaction after thoracoscopic talc poudrage. Chest 2006;129:356-361.

23 Nasreen N, Mohammed KA, Dowling PA, Ward MJ, Galffy G, Antony VB: Talc induces apoptosis in human malignant mesothelioma cells in vitro. Am J Respir Crit Care Med 2000;161:595-600.

24 Nasreen N, Mohammed KA, Brown S, Su Y, Sriram PS, Moudgil B, Loddenkemper R, Antony VB: Talc mediates angiostasis in malignant pleural effusions via endostatin induction. Eur Respir J 2007;29:761-769.

-25 Tschopp JM, Rami-Porta R, Noppen M, Astoul P: Management of spontaneous pneumothorax: state of the art. Eur Respir J 2006; 28:637-650.

26 Noppen M, Dekeukeleire T, Hanon S, Stratakos G, Amjadi K, Madsen P, Meysman M, D'Haese J, Vincken W: Fluorescein-enhanced autofluorescence thoracoscopy in patients with primary spontaneous pneumothorax and normal subjects. Am J Respir Crit Care Med 2006;174:26-30.

-27 Noppen M, Stratakos G, VerbanckS, D'Haese J, Meysman M, Vincken W: Fluorescein-enhanced autofluorescence thoracoscopy in primary spontaneous pneumothorax. Am J Respir Crit Care Med 2004;170:680-682.

28 Noppen M, De Keukeleire T: Pneumothorax. Respiration 2008;76:121-127.

29 De Smedt A, Vanderlinden E, Demanet C, De Waele M, Goossens A, Noppen M: Characterisation of pleural inflammation occurring after primary spontaneous pneumothorax. Eur Respir J 2004;23:896-900. 